\title{
LITERÁRNÍ POSTAVA POVÍDKOVÉ TVORBY ZACHARA PRILEPINA V KONTEXTU NOVÉHO REALISMU
}

\section{MARTINA HUDEČKOVÁ}

\section{LITERARY HERO OF THE SHORT STORIES BY ZAKHAR PRILEPIN IN THE CONTEXT OF THE NEW REALISM}

ABSTRACT The Article is dedicated to a characteristic and typology of literary characters in prosaic text by Zakhar Prilepin. The Literary characters are first of all defined generally from point of various Literary-Scientific approaches. The Analysis of Prilepin's characters is focused on understanding a picture of literary hero in context of new realism that as new way of recent Russian literature brings entirely new view on by Author presented reality and as well changes a character definition like one of the most important and essential category of an art text.

KEY WORDS Zakhar Prilepin, short story, character, new realism, Russian literature CONTACTS University of Ostrava, Faculty of Arts, Department of Slavonic Studies; giamartina@seznam.cz 
Zachar Prilepin je literárními vědci a kritiky vnímán jako autor, jehož texty nesou výrazné znaky nového realismu, literárního směru, který se v ruské literatuře objevuje na počátku 21. století. Tehdy vstupuje do ruské literatury mladá generace autorů (S. Šargunov, I. Senčin, J. Griškovec, D. Bykov, Z. Prilepin aj.), která ostře reaguje na tvorbu postmodernistů, jejichž texty od 90 . let 20. století silně ovlivňují literární dění v Rusku a drží si v pomyslném žebříčku oblíbenosti první místo. Nastupující mladá generace autorů vytýká postmoderním textům (a jejich autorům) parodii, výsměch, zobrazování nereálného světa a především jejich obsahovou vyčerpanost. Šargunov ve svém článku Отрицание траура (2001) píše: „[...] для литературы фатален „постмодернистский эксперимент“. Постмодернизм якобы несовместим с самим существованием литературы“. (Šargunov 2001). Podobné reakce na tvorbu postmodernistů najdeme i v samotné tvorbě Zachara Prilepina, kdy hlavní postava, vyprávějící v povídce Шер аминь svůj zážitek z dětství, nakonec dodává: „Ровно к моему падению грязную лужу как следует раскатал деревенский трактор, чтоб стало сразу пожиже, и погуще [...] Туда и упал я. Пришёл домой весь уделанный, как клоун. Изо рта - грязь; постмодернист, словом.“(Prilepin 2016: 9) Hlavním cílem „nové“ literatury je návrat zpět k realitě, autoři svou pozornost soustřed'ují na každodenní životní situace. Obraz samotného autora je přitom velmi důležitý - musí být výraznou silnou osobností, jež dokáže zaujmout čtenáře, předkládá recipientovi nový směr (literární i životní) oproštěný od pouhých náznaků a nejasných myšlenek. Jeho životní pozice a postoje jsou aparentní a takto se odrážejí i v jeho tvorbě, dodávají textům větší důvěryhodnosti a aktuálnosti. Literárními hrdiny se stávají především mladí lidé vnímající své okolí prizmatem vlastních potřeb, jak o tom píše ve svém článku Jacenko: „Герои этих писателей эгоцентричны: они сфокусированы на собственных чувствах, переживаниях, надеждах и разочарованиях“. (Jacenko 2015). Postava přestává být pouhým objektem postmodernistických her a experimentování, stává se nyní subjektem plně odpovídajícím za své jednání, subjektem nepostradatelným pro další existenci literatury. Typická je pro mladé hrdiny „nové“ literatury silná vůle a impulzivní jednání související s touhou žít a zastávat svou věc, svou ideu. Literární hrdina nového realismu je člověk, který odmítá přijmout skutečnost takovou, jaká doopravdy je. Smyslem života se pro něj mnohdy stává vzdor a vzpoura, které pocituje nejen sám v sobě, ale prezentuje je i navenek ve vztahu k jiným postavám a situacím.

\section{1 / POSTAVY V PRILEPINOVĚ POVÍDKOVÉ TVORBĚ (NA MA- TERIÁLU POVÍDEK ZE SOUBORU CEMЬ ЖИЗНЕЙ)}

Soubor povídek Семь жизней vychází poprvé v roce 2016. Kniha čítá celkem deset povídek, jež se od sebe různí tématy, hlavními postavami i způsoby narace. Možná i právě proto není tento soubor povídek označován (at už autorem, nebo nakladatelem) žádnými podtitulky, jako tomu bylo $u$ předešlých souborů povídek Гpex (podtitulek „роман в рассказах“), Ботинки полные горячей водкой („пацанские рассказы“) а Восьмёрка („восемь историй о мужском мире“). Všechny výše uvedené podtitulky se $\mathrm{v}$ tomto souboru povídek scházejí a vytvářejí mozaikovitý celek z př́běhů, $v$ nichž jsou různé problémy nahliženy prizmatem dětského, dospívajícího i dospělého hrdiny. Povídky nejsou řazeny logicky ani chronologicky, jednotlivé typy postav a jejich charaktery recipient poznává retrospektivně a s poměrně velkým časovým rozestupem, který vytváří relativně ostré hranice při pohledu na postavu a její jednání. 
Prilepin v tomto povídkovém souboru využívá několik typů vyprávění. Z větší poloviny se jedná o vyprávění v 1. osobě, kdy je vypravěč zároveň prožívající hlavní postavou jednotlivých povídek: „Мы сели с бабукой и сидим, она на диване, я на полу. [...] я смотрю на бабуку, пытаясь догадаться о чём-то огромном; мне, наверное, лет пять или меньше.“ (Prilepin 2016: 7-8). Vypravěč se zde ztotožňuje s hlavní postavou a vypráví příběhy, ve kterých vystupuje jako bezejmenná postava já. Pokud bychom se opřeli (jako čtenáři znalí Prilepinovy biografie) o přistup J. Holého, mohli bychom takový typ vyprávění označit jako zpovědní ich-formu, která se od autorského vyprávění liší dominancí prožívajícího subjektu nad vyprávějícím. (Holý 2005) Vyprávění není doprovázeno úvodními pasážemi autorského vypravěče, vypravěč děj a jednání postav nijak neuvádí ani nekomentuje, neoslovuje čtenáře, nepředkládá možné varianty př́běhu, nezamýšlí se nad vybranými strategiemi či pokračováním př́iběhu. Podle Holého „v běžných typech ich-vyprávění s,já jako hrdinou spočívá váha na představovaném ději samém a na občasných sebereflexích ( $\rightarrow$,Zpovědní próza v ich-formě) [...]“ (Holý 2005: 652) Vyvstává zde tedy otázka, převažuje-li v Prilepinových povídkách děj nad postavou či postava nad dějem? Zaměříme-li se jednotlivě na šest konkrétních povídek, jež bychom v rámci souboru Cemb жизней mohli označit jako zpovědní prózu, musíme mít na zřeteli krátký rozsah povídkového textu, který již sám o sobě nedovoluje takovou propracovanost postav či děje, jako je tomu v románu. Hned první povídka Шер аминь představuje jakousi mozaiku životních situací, jejímž pojítkem je pouze hlavní postava. Děj je útržkovitě situován na různá místa (vesnice, město, kasárna), čas vyprávěných událostí plyne chronologicky, od raného dětství až po dospělost. Vyprávějící postava jakoby doslova podávala krátký výčet těch momentů, které ji pozitivně či negativně ovlivnily, byly příčinou a důsledkem jejích následných životních kroků a rozhodnutí, což vypravěč na konci povídky potvrzuje slovy: „Да, любая взрослая победа кажется смешной и мелкой на фоне детского поражения, но что поделаешь.“(Prilepin 2016:23). Hlavní dějová linka (již sama o sobě fragmentární) je navíc místy nabourávána odbočkami v textu, kdy vypravěč přerušuje čas děje a vnáší do př́běhu svou myšlenku: „Прошло двадцать лет, она, наверное, сейчас приготовила борщ мужу - живёт как ни в чём не бывало, всё забыла - так пусть он немедленно ударит рукой о край тарелки - чтоб тарелка сделала в воздухе круг, и капуста на потолок, на люстру, всё вокруг в кипятке, в детском ужасе, - а он, этот муж, как заорёт:Сука! Какого чёрта я связался с тобой!' Кто-то должен за меня отомстить, наконец. Она бы поняла, что тогда, невинный и озыбший, испытал я. ...но нет, муж доест, ничего не скажет, будет прятать в себе самое важное.“ (Prilepin 2016: 12-13). Vyprávějící postava takto naznačuje odstup mezi časem vyprávění a časem vyprávěným - recipient tudíž nevnímá pouze vyprávěný prožitek, je si vědom i určitého časového odstupu, s nímž vypravěč daný př́běh sděluje. Zbylá pětice povídek představuje jednotlivé př́iběhy, jež jsou v každé konkrétní povídce zachyceny jako ucelená, v minulosti prožitá zkušenost. Témata př́běhů se různí - hlavní postava se připravuje a později sživá se svou novou rolí otce, jako voják z povolání se musí vyrovnat s různými existenciálními i psychickými problémy, se svými přáteli proživá zábavné a bezstarostné chvilky posilněn notnou dávkou alkoholu, své nejbližší rodině věnuje veškerou svou lásku a pozornost s vědomím, jak obyčejné, každodenní životní chvilky dokážou člověku dát tolik energie a smysl života. Jak jsme si nyní ukázali, děj jednotlivých povídek bychom vždy mohli shrnout jednou větou. Domníváme se, že v Prilepinových povídkách není výhradně dominující složkou děj příběhu. Je to právě vypravěč, jenž je u Prilepina prožívající 
postavou, která dílčím způsobem na ději participuje. Je jejím hybatelem v rámci sjednocování dějové linky, stává se do určité míry kličem ke smyslu povídek (jak v rámci souboru povídek Семь жизней, tak i např́č celou Prilepinovou povídkovou tvorbou). Je to právě hlavní postava, která svými činy pomáhá čtenáři skládat z jednotlivých útržků celkový obraz.

Hlavní postava je Prilepinem v jednotlivých povídkách zobrazována v různých vztazích k sobě samé, k ostatním postavám a ve vztahu k chronotopu, jenž její jednání významně ovlivňuje. Celkový náhled na sebe, své tělo a fyzické schopnosti je diferencován především věkem hlavní postavy a jejími životními zkušenostmi. V dětském věku si připadá jako outsider, kterému se skoro nic nedaří. Ani v dospívajícím věku, kdy se pokouší najít lásku, ale přichází pouze odmítnutí, se plnohodnotně nenaplňují představy hlavní postavy o životě. Až mladá dospělost s sebou konečně přináší první opravdové životní zkušenosti - službu v armádě, první známost i první zklamání v lásce. Dospělý život pak postava prožívá se svou rodinou a přáteli, aktivně se účastní válečného konfliktu v Čečně, vykonává řadu nejrůznějších profesí pro materiální zabezpečení svých nejbližších. Pohledem zralého čtyřicátníka se zamýšlí nad sebou a svou životní situací: „Мало кто на земле чувствует себя так же хорошо, как я. Просыпаюсь и думаю: как же мне хорошо. Засыпаю и думаю: хорошо. Не спрашиваю отчего. Не прошу ничего нового. Тихо прошу: оставь всё как есть хотя бы ещё немного.“ (Prilepin 2016: 219). „От меня не останется здесь ничего. К сорока годам я заработал столько, что мог ещё десять лет только тратить - понемногу, естественно, но когда мне было нужно многое.“(Prilepin 2016: 228).

Svůj vztah k jiným postavám - nejčastěji jsou to rodinní př́slušníci (rodiče, manželka, děti) a přátelé (tzv. nацаны) - samotná hlavní postava charakterizuje slovy: „Мир разделился на две половины - одни дружат со мной, другие слабее меня. Есть ещё какие то третьи, но нам нет дела друг до друга. От меня ушли только те, кого я не любил, а кого я люблю - остались со мной.“ (Prilepin 2016: 20). Láska, o které mluví, má vícero podob. Především je to jeho láska k ženě, kterou miluje, a ke svým dětem. Tuto lásku přijímá od Boha jako dar, cítí potřebu ji nejen přijímat, ale také mnohonásobně vracet. Stává se pro něj jakýmsi talismanem, rodina mu dodává životní sílu, optimismus a pocit štěstí. Cítí povinnost ji chránit a starat se o ni za všech okolností, jeho nejbližší jsou mu tím nejcennějším, co na tomto světě má a dává to svými slovy nesčetněkrát najevo: „Как я психовал всё это время! Как я был унижен. У меня была беременная жена, а я не мог даже её толком прокормить её и нашего космонавта на додлёте.“ (Prilepin 2016: 87). „В руках жена держала кулёк с младенцем. - Смотри, малыш, это наш папа, - сказала моя любимая. - Он будет заботиться о тебе.“ (Prilepin 2016: 103).

Př́značné je pro postavy Prilepinových povídek tzv. nau,aнсmвo, které není pouhým označením mladých chlapeckých postav konkrétního věku. Je to především styl a způsob života, osobitý typ přátelství mezi muži. Паu,aны představují malou skupinku přátel, jež spojuje neobvyklá mluva, přehnané maskulinní chování a časté popíjení alkoholu. Tito přátelé jsou vždy nablízku, pokud je hlavní hrdina potřebuje, jsou to lidé upřímní, pevně zastávající své názory, protestující proti všemu, co je v rozporu s jejich přesvědčením. V mnohém jsou si s hlavní postavou podobní, jak můžeme vidět z popisu postavy Pavlenka, (povídka Спички и maбaк, и всё maкое), kterého vypravěč vystihuje slovy: „Павленко был питерский нацбол со стажем, фигурант как минимум восьми уголовных дел по разнообразному злостному оппозиционному 
хулиганству, яростный ,левак', безусловный русский империалист, и посему в государственных понятиях того времени - гулёвщик, негодяй.“ (Prilepin 2016: 108). Všechny životní momenty, které hlavní postavu nějakým způsobem ovlivňují a formují její životní postoje, jsou úzce spjaty s konkrétním místem a časem. Právě chronotop je v povídkách tou literární kategorií, která výrazným způsobem dotváří celkový obraz hlavní postavy. Postava je v chlapeckých letech formována životem na vesnici, ve vzpomínkách si vybavuje své rodiče i prarodiče, známé, sousedy, klukovské hry i nezdary. V dospívajícím věku se ocitá ve městě, mění se tak její školní i sociální prostředí, postupně se utváří její sebevědomí a názory na okolní svět. Zde je důležité podotknout, že hlavní postava dospívá v 90. letech 20. století, v době politických, ekonomických, kulturních a jiných změn, které hýbou celým tehdejším Ruskem. Sebe sama jako dospělého jedince, připraveného čelit všem životním nástrahám a nést za své činy plnou odpovědnost, vnímá hlavní postava následovně: „Мы - я и несколько моих плюс-минус ровесников [...] родившиеся, выросшие и отслужившие кто где смог в прошлом веке, пришедшие в новое тысячилетие не только с зажигалкой в виде черепахи, но и с багажом, который можно было выгодно представить на ярмарке тщеславия, удачи и надежды. Я стал называться: сочинитель, литератор." (Prilepin 2016: 17-18). Doba uplynulá je vnímána jako ta, kterou hlavní postava vzhledem ke svému věku nemohla nijak výrazně ovlivnit, ovšem mohla k ní zaujmout určité stanovisko, utvořit si vlastní názor a později využít dřivějších zkušeností k vybudování vlastního pevného životního postoje.

Propracovanost hlavní postavy a jejích vzájemných vztahů k jiným postavám je dynamického charakteru - poznáváme ji postupně prostřednictvím popisu vnějšího vzhledu postavy, jejího jednání, promluv, líčení pocitů a myšlenek, dialogů mezi postavami a vnitřních monologů hlavní postavy. Pokud shrneme všechny tyto způsoby, jimiž je hlavní postava u Prilepina vylíčena, všimneme si atributu charakteristického pro realistickou literaturu - totiž pokusu o její (v minimalistickém rozsahu) komplexní prezentaci, i když v různé míře užití konkrétních způsobů jejího zobrazení, jak o tom píše D. Hodrová (Hodrová 2001). Nejvíce se o hlavní postavě dozvídáme z jejího jednání a promluv - postava se čtenáři otevírá, vyjadřuje své myšlenky a názory, svůj pohled na okolní svět: „Я не мог сказать: какой он милый! - это слово я не использовал в обыденной речи, я же мужчина.“(Prilepin 2016: 80). Občas v textu narazíme i na popis vnějšího vzhledu postavy: „[...] я посмотрел на себя в зеркало заднего вида. Небритое, невыспавшееся лицо безработного шалопая. [...] На ноге моей была сандалия, на лбу - дурацкая панамка, лацкан отсутствовал вместе с пиджаком.“ (Prilepin 2016: 74). $S$ přimou charakteristikou, jak ji ve svých textech Prilepin uživá, velmi úzce souvisí sociální zařazení postavy a její role ve společnosti - shrnutím povídek v jeden celek vidíme postavu milujícího přítele, manžela a otce, retrospektivně pak postavu kamaráda, spolužáka či vojáka, dobrovolně sloužícího své zemi. Každá z těchto životních rolí je pro hlavní postavu klíčová a udává její vývoj.

Jestliže jsme výše zmiňovali tzv. zpovědni typ vyprávění s občasnými sebereflexemi, jsou tyto v Prilepinových povídkách vyjadřovány skrze vnitřní monolog postavy, který spoluvytváří její momentální psychický a duševní stav: „Мне было жаль Фёдора, и ещё - я гнал эту мысль мне стало стыдно. [...] До появления космонавта на поводке - моего голубозлазого пескаря - я не был так сентиментален. Что со мной творится вообще!“ (Prilepin 2016: 86). Tyto sebereflexe jsou pro vykreslení hlavní postavy velmi důležité, nebot v konečném důsledku 
ovlivňují její jednání. I když se hlavní postava navenek mnohdy chová impulsivně či nepřiměřeně, uvnitř pak svádí vnitřní boj sama se sebou a se svým svědomím, př̌emýšlí nad svými činy.

Prilepin ve svých povídkách vytváří hlavní postavu jedinečnou, která není představitelem obecné entity, jak o tom píše P. A. Bílek (Bílek 2003: 163). Postavu tvoří soubor vlastností, myšlenek a pevných životních postojů. Je to právě její individualita, která do vyprávěného textu vstupuje a významově celý text svým úhlem pohledu ovlivňuje. Pokud bychom se z hlediska funkce postavy $\mathrm{v}$ textu opřeli o Bílkovo rozdělení fungování postavy jako mimetického obrazu nebo textového konstruktu, mohli bychom dost dobře využít obou těchto protipólů. O hlavní postavě můžeme hovořit jako o "reálné" postavě, která se do určité míry stává mimetickým obrazem, jelikož odkazuje do reálného světa. $V$ tomto případě se však nevyhneme otázce nad vztahem fikčnosti a reálnosti, jelikož Prilepinova hlavní postava není „tou“ postavou, která je „[...] charakterizovaná vlastním jménem i atributy, které $\mathrm{k}$ ní máme priiřazeny na základě našich historických, kulturních či dobově sociologických znalostí [...]." (Bílek 2003: 160). Jedná se rovněž o textový konstrukt, o postavu fungující a žijící v rámci literárního textu, ne uvnitř skutečného, reálného světa.

Součástí povídkového souboru Семь жизней jsou rovněž povídky, v nichž autor nechává promlouvat třetí, nezaujatou osobu, jež je pouhým pozorovatelem a zprostředkovatelem př́běhu. Odlišným způsobem vyprávění zde vybočují čtyři z nich - Попутчики, Зима, Петров a Ближний, дальний, ближний. $\mathrm{V}$ těchto povídkách se již nesetkáváme s hlavní postavou-vypravěčem, která by vyprávěné situace zároveň prožívala. První povídka Попymчuкu je př́iběhem o skupince známých, kteří se, posilněni alkoholem, vypraví do sauny, kde si chtějí užít volný čas. Autor zde jménem nazývá pouze hlavního hrdinu Верховойского, ostatní postavy skrývají svou identitu pod názvy profesí (таджикская певица, армянский массажист, писатель-почвенник, драматург, стриптизёрша). Přátelství, nespoutaná zábava a alkohol jsou hlavními motivy povídky - vidíme zde, v poněkud modifikované podobě, již výše zmíněné nau,aнсmвo. Povídka Зима je svým způsobem osobitá, neznáme ani jméno hlavního hrdiny, nedokážeme z tak krátkého textu zrekonstruovat jeho charakteristiku. Př́běh se odehrává jednoho časného rána, kdy se hlavní hrdina vydává na procházku ze svého hotelu (zanechávaje tam svou spící př́telkyni) $\mathrm{k}$ moři. Př́běh je vystavěn především na popisování okolní krajiny a pocitů, jež hlavní hrdina z těchto scenérí kolem sebe má, jeví se spiše impresionistickým než realistickým. Zdánlivě obyčejné všední momenty doplňuje motiv lásky: „[...] и так понятно, как невыносимо он любил всё это, держа в руках её голову, дыша светлыми, влажными волосами и находя то, что видел, совершенным: ноздри, маленькие, как у куклы, мочки ушей, прохладные и тоже до смешного маленькие, линию лба, родинку на виске, сам висок, шею..." (Prilepin 2016: 61). V povídce s názvem Петров Prilepin vytváři poněkud protikladnou postavu $\mathrm{k}$ té, se kterou se setkáváme v povídkách s hlavní postavou-vypravěčem. Všechny rysy, které jsou typické pro postavu-vypravěče, tato postava Петрова neguje - v životě nepotřebuje lásku, manželku ani děti, vykonává stále stejnou profesi, kvưli špatnému zdravotnímu stavu neprošel vojenským výcvikem, př́liš se nezabývá sebou samým ani okolím: „Жизнь его текла и текла, к рефлексии Петроф склонен не был и, если задумывался иногда о себе, считал, что всё впереди.“ (Prilepin 2016: 124). Jeho způsob života je nudný, stejně jako bylo nudné celé jeho dětství, které prožil v городской хрущёвке se svou matkou, která je jen stěží uživila. Postava Петрова postrádá životní optimismus a energii, je svébytným prototypem člověka přeživajícího jen ze dne na den. 
V povídce Ближний, дальний, ближний se vypráví př́běh, jehož hlavním hrdinou je „otec rodiny", pro něhož jsou okamžiky prožité s nejbližší rodinou tím nejdůležitěǰš́m smyslem života: „Когда утром отец семейства входил в детскую комнату, он всякий раз, заворожённый, застывал при виде старшей дочери. [...] Всё её, ещё юное тело, от мизинчика на ноге до мизинчика на руке, - являло собой торжество природы, чистоты, свежести и необычайного Господнего вдохновения [...]“ (Prilepin 2016: 198). Jestliže se na tomto místě opět vrátíme $\mathrm{k}$ otázce pohybu mezi reálným a fiktivním světem $\mathrm{v}$ Prilepinových krátkých prózách, mohlo by být pro nás klíčem právě stř́ídání různých hledisek a vyprávěcích situací, které jsme si nastínili výše. Jak píše ve svém textu Typy vyprávění J. Holý, pokud v té či oné míře „[...] vstupují dokumenty či reálně viděný a prožívaný svět do rámce literárního díla, stávají se pochopitelně jeho součástí, tedy rovněž fikcemi." (Holý 2005: 666). I když v Prilepinových povídkách čteme o událostech, které více či méně odkazují k autorovu vlastnímu životu, nacházíme se stále uvnitř fikčního literárního světa, který ovšem, na rozdíl od postmoderny, vykazuje znaky obecně platných představ o reálném světě.

Výrazným rysem novorealistických postav je rovněž sepětí s autorem, který do suých textů vkládá autobiografické prvky, opírá se o své vlastní zkušenosti a prožitky, zpracovává témata, která jsou mu blízká. Nejinak je tomu u postav z Prilepinových povídek (a nejen povídek). Autor čerpá ze svých vlastních životních zkušeností, které nabyl jako voják v Čečně (povídky, rovněž i romány Патологии а Санькя), jako řidič či vyhazovač v nočním klubu (povídkové soubory), nebo jako účastník ozbrojených konfliktů na Donbasu (román Некоторыe не nonadym в ад). Novorealistická hlavní postava však vykazuje oproti klasické realistické postavě jiné rysy - Prilepin netvoří hlavní postavu jako objekt, od kterého je vzdálen, nýbrž jako subjekt $s$ vlastní nezaměnitelnou individualitou, který se autorovi nápadně podobá. Máme zde ovšem na zřeteli, že v rámci Prilepinových textů jsou to stále jen postavy, které „[...] nemohou být zcela skutečné už pro svou literární zprostředkovanost; literární postava svými obrysy vždy nějak přečnívá, nebo naopak zcela nepokrývá reálný předobraz, zůstává tedy vždy v té či oné míře hypotetická, i když je jejím předobrazem skutečná osoba.“ (Hodrová, 2001: 551)

Jednotlivé postavy Prilepinových povídek vykazují podobné, ne-li shodné rysy. O. Osmuchina je svém článku Образ героя в прозе Захара Прилепина definuje јako „[...] стремление к духовному поиску, свободолюбие, независимость, чувство собственного достоинства, право на самоопределение и осознанный выбор (нравственный, жизненный и т. д.), крайний максимализм.“ (Osmuchina 2018). Zároveň autorka ale dodává, že mezi literárními hrdiny Prilepinových próz existují také rozdíly, kdy někteří si navzdory prožitým životním situacím stále zachovávají svou lidskost, zatímco druzí ji v sobě potlačují s cílem prosadit konkrétní ideu, za kterou jsou ochotni doslova bojovat až do posledního momentu. Kočněv popisuje hrdiny Prilepinových textů jako „[...] героев тяжелого хемингуэевского типа, крепких, суровых и преданных делу мужчин [...] провозглашают они ценности отнюдь не маргинальные (как персонажи Эдуарда Лимонова), а вполне буржуазные - семья, долг, общество и т. п.“ (Kočněv 2013). Pro takové typy hrdinů má Kočněv výraz „хомо сапиенс борющийся“, jsou to hrdinové pevně stojící na nohou, úspěšně bojující za své životní ideály a jistoty, přesvědčeni vytrvat ve svém úsilí. Hlavní postava Prilepinových povídek se snaží postihnout obraz okolního světa prostřednictvím vlastního prožívání a vlastního osudu, přičemž se ani na okamžik neodklání od reality, ta je pro něj naopak pevným bodem, jistotou. Skrze literární postavu tak 
Prilepin vyjadřuje své postoje k okolnímu světu a nechává postavu znovu prožívat některé momenty ze svého života.

\section{LITERARY HERO OF THE SHORT STORIES BY ZAKHAR PRILEPIN IN THE CONTEXT OF THE NEW REALISM}

SUMMARY The article points out the way in which Russian writer Zakhar Prilepin creates in his short stories a completely distinctive type of hero. The literary hero might be seen not only separately in the context of Prilepin's short story work, but also in relation with the new realism of which the author is the main representative. The heroes of Prilepin's short stories are mostly an alter-ego of the author himself, who puts a number of autobiographical elements into the stories, which links the author to the depicted character. The characters are portrayed in everyday situations in the real world that lately surrounds us. These are self-confident characters with a clear goal in life, promoting their views and attitudes regardless of the current situation, regardless of the opinions of others. Prilepin's literary hero is a personality who does not act for the benefit of the public, but for the benefit of his, his loved ones and his own beliefs. He presents his firm views to society and a surrounding world without embellishment like it really is. The characters are typical of their often internal monologue by means of which reveal not only their outwardly hidden feelings but also uncover to us a part of their soul, their desires and valuables of life. Throughout all his stories, Prilepin still creates the same type of hero, changing only the situations and environments that determine his behavior and actions.

\section{LITERATURA}

\section{Spisy}

I Bílek P. A., 2003, Hledání jazyka interpretace k modernímu prozaickému textu, Brno.

I Hodrová D., 2001...na okraji chaosu..., Praha.

I Holý J., 2005, Typy vyprávění. Na cestě ke smyslu. Poetika literárního díla 20. století, Praha.

I Prilepin Z., 2011, Botky plné horké vodky, Praha.

I Прилепин 3., 2016, Восьмёрка, Москва.

I Прилепин 3., 2015, Грех, Москва.

/ Прилепин 3., 2016, Семьжизней, Москва.

\section{Články}

I Кочнев В., Смерть маргинального героя. [Online] Dostupné z: https://magazines.gorky. media/october/2013/8/smert-marginalnogo-geroya.html

I Новикова Е. О., Новый реализм - его авторы и герои. [Online] Dostupné z: https:// cyberleninka.ru/article/n/novyy-realizm-ego-avtory-i-geroi/viewer 
I Осьмухина О. Ю., Образ героя в прозе Захара Прилепина (на материале романов Патологии, Санькя). [Online] Dostupné z: https://cyberleninka.ru/article/n/obraz-geroya-v-proze-zahara-prilepina-na-materiale-romanov-patologii-sankya/viewer

I Шаргунов С., Отрицание траура. [Online] Dostupné z: https://magazines.gorky.media/ novyi_mi/2001/12/otriczanie-traura.html

I Яценко И. И., Современная русская проза как источник знаний о стране (в преподавании русского языка как иностранного). [Online] Dostupné z: https://cyberleninka.ru/article/n/ sovremennaya-russkaya-proza-kak-istochnik-znaniy-o-strane-v-prepodavanii-russkogo-yazyka-kak-inostrannogo 